DOI: $10.2478 / \mathrm{v} 10025-012-0003-2$

JOURNAL OF WATER

AND LAND DEVELOPMENT

J. Water Land Dev. No. 15, 2011: 29-40

\title{
Characteristics of grasslands in the Polish Sudetes in view of fodder production potential and grassland protection
}

\author{
Longina NADOLNA, Marta ŻYSZKOWSKA
}

Institute of Technology and Life Sciences, Lower Silesian Research Centre in Wrocław, ul. Gen. Z. Berlinga 7, 51-209 Wrocław, Poland; 1.nadolna@itep.edu.pl

\begin{abstract}
Mountain region of the Sudetes has a productive potential that allows for obtaining high quality fodder from grasslands. The potential is facilitated by the fact that $94 \%$ of grassland area is situated below the elevation of $700 \mathrm{~m}$ a.s.l. and $75 \%$ of them on slopes inclined less $9^{\circ}$. Meadows and pastures of the highest economic importance cover an area larger than 50000 ha, most of them situated in the Kłodzko district. The analysis of ruminant and horse stock in 2008 revealed that the possibilities of fodder production largely exceeded the demands. Productive use of meadows and pastures loses importance, particularly in the Jelenia Góra district, despite financial support within the Common Agricultural Policy of the EU.
\end{abstract}

Key words: fodder production, grasslands, livestock population, the Sudetes

\section{INTRODUCTION}

The Sudetes have all features of mountain areas, that significantly determine the function of these areas in spatial management. Agricultural areas in the region constitute ca. $50 \%$ of the total area. In the agricultural areas structure, grasslands cover almost $40 \%$, and in some districts - even $100 \%$. This status has persisted till now despite changing trends in agricultural development during the post-war period. The following periods can be distinguished in that development:

- collectivisation of agriculture which directly triggered the depopulation of rural areas,

- organisation of fodder bases for young beef cattle in order to utilise grasslands created on barren arable lands,

- lower profitability of animal production after 1990 and a drastic decline in cattle and sheep stock which resulted in the shrinking of grassland areas, some of which were abandoned and some turned to a different form of land use. 
The aforementioned history of meadow and pasture management, especially its last stage, affected the environmentally and economically valuable meadow and pasture communities so that they started to lose the features which had enabled them to fulfil their productive and non-production functions.

Actions undertaken within the Common Agricultural Policy and the system of areal subsidies and compensations implemented in Poland since 2004 facilitated the restoration of agricultural land use, particularly in areas of favourable conditions for agricultural production. The rate of grassland abandoning decreased. Now, the area of fallow grasslands in four districts of the region (Kłodzko, Wa1brzych, Kamienna Góra and Jelenia Góra) decreased by half and does not exceed $15 \%$ out of 80000 ha of meadows and pastures (Stan..., 2007). Breeding ruminants based on fodder from grasslands should be the main direction of agricultural production in mountain areas in view of the economic and biological reasons.

The aim of this study was the characteristic and assessment of grasslands in the Sudetes in view of possible fodder production in relation to the demands of ruminants and horses in the region.

\section{STUDY AREA}

Mountain region of the Polish Sudetes was the study area, its southern range is delineated by the course of main crests along the border with the Czech Republic

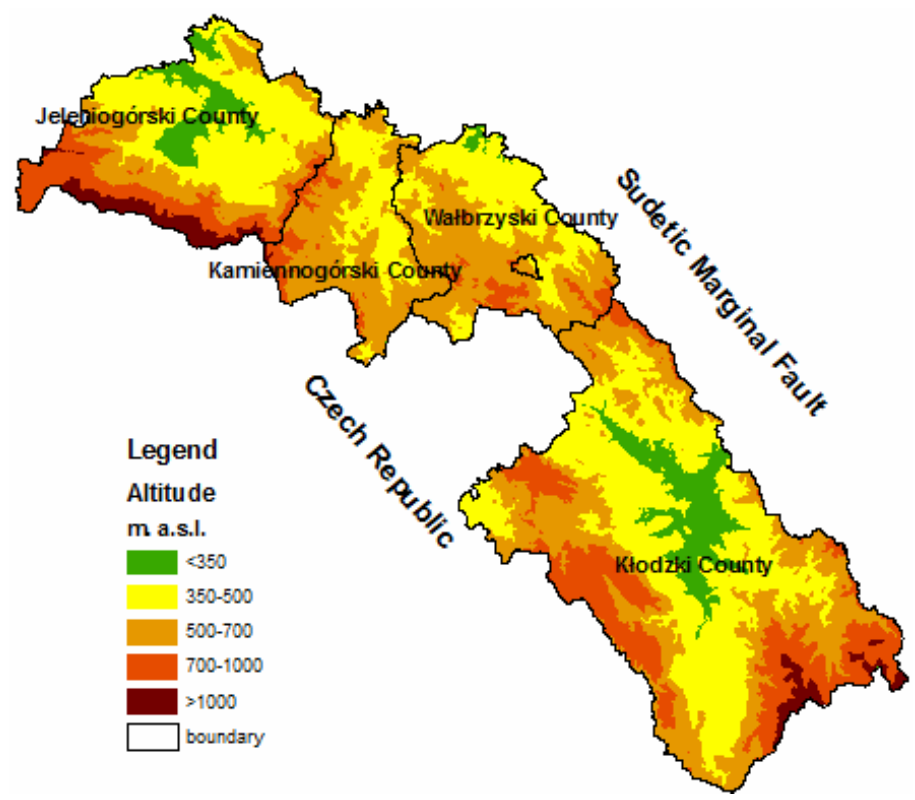

Fig 1 . The study area 
and north-eastern range is drawn by a line of the Sudetic Marginal Fault largely corresponding to the $300 \mathrm{~m}$ a.s.l. contour line. The Sudetes are old mountains and the highest out of medium European mountains. One third of their area is localised in Poland and constitutes about 3\% of the district area. Valley depressions and passes divide the mountains into the Western, Central and Eastern Sudetes. The highest peaks in the region are: Śnieżka - $1602 \mathrm{~m}$ a.s.l. in the Western Sudetes and Śnieżnik - 1425 m a.s.l. in the Eastern Sudetes. The area under study (329 064 ha) included four districts: Jelenia Góra (73 609 ha; $58 \%$ of grasslands in the area of agricultural areas), Kamienna Góra (38 829 ha; $60 \%$ of grasslands), Kłodzko (164 237 ha; 44\% of grasslands) and Wałbrzych (51 389 ha; $54 \%$ of grasslands) (Fig. 1).

\section{METHODS}

Analyses were performed by use of a digital database containing: Digital Terrain Model (including hypsometry, inclination, exposure) made of 1:10 000 maps as well as land cover and soil - type maps in the scale 1:5000. In order to obtain information about the quality and location of grasslands in the region, all data layers were overlaid. The resulting layer contains the attributes of all input layers. This allowed to select the areas that meet criteria based on information from these layers. The whole analysis was carried out in ArcGIS 9.3, with the slope calculation, the altitude and the exposure made in the Spatial Analyst extension. In the next step a grassland classification was carried out. Grassland areas were classified based on soil-agricultural complexes: very good and good (1z), medium (2z) and poor or very poor (3z). Complex $1 \mathrm{z}$ included grasslands situated on soils of the I and II soil quality class, complex $2 z$ - those of the III and IV class and $3 z-$ those of the V and VI class. They were set up in relation to altitude zones: $<350,350$ 500, 500-700, 700-1000 and $>1000 \mathrm{~m}$ a.s.l. (keeping in mind the criteria for LFA areas and the altitude $700 \mathrm{~m}$ a.s.l., as an upper limit of agricultural use in the Sudetes), slope classes: $<3^{\circ}, 3-7^{\circ}, 7-9^{\circ}, 9-12^{\circ}, 12-15^{\circ}$ and $>15^{\circ}$ (where the slope of $9^{\circ}$ is a threshold value in excluding grasslands from the afforestation) and exposure according to 8 directions: N, NE, E, SE, S, SW, W, NW and flat areas, as an important factor in shaping the upland habitats (FATYGA, 2003; Journal..., 2007).

The demand for fodder production was analysed based on ruminant and horse stock acc. to agricultural census of the year 2002 and data of 2008 collected by the Lower Silesian Centre of Agricultural Advisory in Wrocław with respect to the four studied districts (Spis..., 2002; Zestawienie..., 2008). 
Table 1. Grassland area (ha) according to elevation zones

\begin{tabular}{|c|c|c|c|c|c|c|c|c|c|c|c|c|}
\hline $\begin{array}{l}\text { Grassland's } \\
\text { complexes }\end{array}$ & ha & $\%$ & ha & $\%$ & ha & $\%$ & ha & $\%$ & ha & $\%$ & ha & $\%$ \\
\hline $1 z$ & 0 & & 9 & 0 & 0 & & 0 & & 0 & & 9 & 0 \\
\hline $2 \mathrm{z}$ & 2592 & 14 & 8432 & 46 & 1553 & 9 & 34 & 0 & 0 & 0 & 12611 & 69 \\
\hline $3 z$ & 291 & 2 & 2576 & 14 & 2216 & 12 & 401 & 2 & 115 & 1 & 5598 & 31 \\
\hline $1 z$ & 0 & & 0 & & 0 & & 0 & & 0 & & 0 & \\
\hline $2 \mathrm{z}$ & 1 & 0 & 4835 & 36 & 5737 & 43 & 117 & 1 & 0 & & 10689 & 79 \\
\hline $3 z$ & 0 & 0 & 495 & 4 & 1813 & 14 & 482 & 4 & 0 & 0 & 2790 & 21 \\
\hline \multirow[t]{2}{*}{ Total } & 1 & 0 & 5330 & 40 & 7550 & 56 & 599 & 4 & 0 & 0 & 13479 & 100 \\
\hline & \multicolumn{12}{|c|}{ Kłodzko district } \\
\hline Total & \multicolumn{12}{|c|}{ Wałbrzych district } \\
\hline $1 z$ & 0 & & 0 & & 0 & & 0 & & 0 & & 0 & \\
\hline $2 z$ & 198 & 1 & 4290 & 29 & 5269 & 35 & 138 & 1 & 0 & 0 & 9895 & 66 \\
\hline $3 z$ & 42 & 0 & 1292 & 9 & 3408 & 23 & 370 & 3 & 0 & 0 & 5111 & 34 \\
\hline \multirow[t]{2}{*}{ Total } & 239 & 2 & 5582 & 37 & 8677 & 58 & 508 & 3 & 0 & 0 & 15006 & 100 \\
\hline & \multicolumn{12}{|c|}{ Total } \\
\hline $1 z$ & 147 & 0 & 58 & 0 & 0 & & 0 & & 0 & & 205 & 0 \\
\hline $2 z$ & 6023 & 7 & 30990 & 37 & 19020 & 23 & 1197 & 1 & 0 & & 57229 & 68 \\
\hline $3 z$ & 586 & 1 & 7389 & 9 & 14485 & 17 & 3592 & 4 & 127 & 0 & 26179 & 31 \\
\hline Total & 6763 & 8 & 38474 & 46 & 33527 & 40 & 4790 & 6 & 127 & 0 & 83613 & 100 \\
\hline
\end{tabular}




\section{RESULTS}

Distribution of grasslands acc. to soil-agricultural complexes in relation to elevation is presented in Table 1. The data show that grassland area in the four Sudetes districts is 83613 ha. Large part of grasslands $-94 \%$ or c. 80000 ha is situated beneath the contour line of $700 \mathrm{~m}$ a.s.l. which is the upper range of agricultural utilisation in the Sudetes. Forty six percent of grasslands grow in the zone 350-500 m a.s.l. and $40 \%$ - between 500 and $700 \mathrm{~m}$ a.s.l.

Medium soil-agricultural complex of grasslands $(2 z)$ dominates in the region covering c. 70\% (57 229 ha) of the total area. Thirty seven percent (31 000 ha) of this area is situated between 350 and $500 \mathrm{~m}$ a.s.l. and 23\% (19 $020 \mathrm{ha}$ ) in the upper zone between 500 and $700 \mathrm{~m}$ a.s.l. Poor and very poor grasslands (complex 3z) occupy 31\% (26 $179 \mathrm{ha}$ ) and their largest area (17\% i.e. $14500 \mathrm{ha})$ stretches out between 500 and $700 \mathrm{~m}$ a.s.1. Very good and good grasslands $(1 \mathrm{z})$ constitute only $0.2 \%$ (205 ha) of the total area. They range up to $500 \mathrm{~m}$ a.s.l. and their largest part is situated beneath $350 \mathrm{~m}$ a.s.l.

In valley districts (Jelenia Góra and Kłodzko) grasslands are mainly situated in the zone $350-500 \mathrm{~m}$ a.s.l. and their contribution is $61 \%$ and $45 \%(11000$ and 16500 ha), respectively. Grasslands in mountain districts (Kamienna Góra and Wałbrzych) are mainly situated in the higher zone between 500 and $700 \mathrm{~m}$ and occupy 7550 and 8680 ha (56 and 58\%), respectively. Noteworthy are the districts of Jelenia Góra and Kłodzko where $60 \%$ and $45 \%$, respectively, of meadows and pastures from the complex $2 \mathrm{z}$ are situated below $500 \mathrm{~m}$ a.s.l.

The analysis of grassland distribution showed that more than $75 \%$ of their area (62400 ha) cover slopes of an inclination of less than $9^{\circ}$ with $31 \%$ on slopes inclined less then $3^{\circ}, 26 \%$ on slopes with the inclination between 3 and $6^{\circ}$ and $18 \%$ on slopes inclined by $6-9^{\circ}$ (tab. 2$)$. On more steep slopes $\left(>12^{\circ}\right)$ there were $12 \%$ of grasslands.

Meadows and pastures of the $2 \mathrm{z}$ complex were mainly localised in the first two classes of slope inclination ( 26 and $20 \%$, respectively) and the area of grasslands from poor complex $3 z$ increased with the increase of slope inclination up to $20^{\circ}$. In the class above $20^{\circ}$ inclination grasslands from both $2 \mathrm{z}$ and $3 \mathrm{z}$ complexes occupied very small areas.

Similar trends could be observed in particular districts though the Jelenia Góra and Kamienna Góra districts were characterised by a high share of medium $2 \mathrm{z}$ grasslands (32 and 35\%, respectively) situated on slopes with $<3^{\circ}$ inclination.

Studied grasslands were mainly situated on slopes of cool, northern to eastern exposures (N, NE, E, NW) favourable due to a smaller risk of water deficits in the vegetation season (tab. 3). Their share on slopes of these exposures reached $52 \%$ (43 277 ha) with the domination of northern and north-eastern exposure $(15 \%$ each). 
Table 2. Grassland area (ha) according to inclination classes

\begin{tabular}{|c|c|c|c|c|c|c|c|c|c|c|c|c|c|c|}
\hline $\begin{array}{l}\text { Grassland's } \\
\text { complexes }\end{array}$ & ha & $\%$ & ha & $\%$ & \begin{tabular}{l|l} 
ha & \\
\end{tabular} & $\%$ & \begin{tabular}{l|l} 
ha \\
\end{tabular} & $\%$ & ha & $\%$ & ha & $\%$ & ha & $\%$ \\
\hline $1 z$ & 0 & 0 & 4 & 0 & 5 & 0 & 0 & 0 & 0 & 0 & 0 & 0 & 9 & 0 \\
\hline $2 \mathrm{z}$ & 5913 & 32 & 3220 & 18 & 2044 & 11 & 977 & 5 & 447 & 2 & 9 & 0 & 12611 & 69 \\
\hline $3 z$ & 1048 & 6 & 1144 & 6 & 1334 & 7 & 1204 & 7 & 1004 & 5 & 64 & 0 & 5798 & 32 \\
\hline $1 z$ & 0 & & 0 & & 0 & & 0 & & 0 & & 0 & & 0 & 0 \\
\hline $2 z$ & 4717 & 35 & 3296 & 25 & 1544 & 12 & 679 & 5 & 428 & 3 & 25 & 0 & 10689 & 79 \\
\hline $3 z$ & 388 & 3 & 489 & 4 & 572 & 4 & 631 & 5 & 668 & 5 & 41 & 0 & 2790 & 21 \\
\hline \multirow[t]{2}{*}{ Total } & 5105 & 38 & 3786 & 28 & 2116 & 16 & 1310 & 10 & 1096 & 8 & 67 & 1 & 13479 & 100 \\
\hline & \multicolumn{14}{|c|}{ Kłodzko district } \\
\hline Total & \multicolumn{14}{|c|}{ Wałbrzych district } \\
\hline $1 z$ & 0 & & 0 & & 0 & & 0 & & 0 & & 0 & & 0 & \\
\hline $2 \mathrm{z}$ & 2715 & 18 & 2980 & 20 & 2034 & 14 & 1188 & 8 & 899 & 6 & 78 & 1 & 9895 & 66 \\
\hline $3 z$ & 498 & 3 & 901 & 6 & 1101 & 7 & 1088 & 7 & 1354 & 9 & 169 & 1 & 5111 & 34 \\
\hline \multirow[t]{2}{*}{ Total } & 3214 & 21 & 3882 & 26 & 3134 & 21 & 2276 & 15 & 2254 & 15 & 247 & 2 & 15006 & 100 \\
\hline & \multicolumn{14}{|c|}{ Total } \\
\hline $1 z$ & 163 & 0 & 26 & 0 & 13 & 0 & 2 & 0 & 2 & 0 & 0 & 0 & 205 & 0 \\
\hline $2 z$ & 21943 & 26 & 16447 & 20 & 9853 & 12 & 5357 & 6 & 3407 & 4 & 222 & 0 & 57228 & 68 \\
\hline $3 z$ & 3447 & 4 & 4972 & 6 & 5540 & 7 & 5596 & 7 & 6144 & 7 & 681 & 1 & 26379 & 32 \\
\hline Total & 25553 & 31 & 21445 & 26 & 15406 & 18 & 10955 & 13 & 9552 & 11 & 903 & 1 & 83813 & 100 \\
\hline
\end{tabular}


Table 3. Grassland area (ha) according to exposure

\begin{tabular}{|c|c|c|c|c|c|c|c|c|c|c|c|c|c|c|c|c|c|c|c|c|}
\hline \multirow{3}{*}{$\begin{array}{l}\text { Grassland's } \\
\text { complexes }\end{array}$} & \multicolumn{18}{|c|}{ Exposures } & \multirow{2}{*}{\multicolumn{2}{|c|}{ Total }} \\
\hline & \multicolumn{2}{|l|}{$\mathrm{N}$} & \multicolumn{2}{|l|}{$\mathrm{NE}$} & \multicolumn{2}{|l|}{$\mathrm{E}$} & \multicolumn{2}{|c|}{ NW } & \multicolumn{2}{|c|}{$\mathrm{S}$} & \multicolumn{2}{|c|}{ SW } & \multicolumn{2}{|c|}{ W } & \multicolumn{2}{|l|}{ SE } & \multicolumn{2}{|c|}{ Flat } & & \\
\hline & ha & $\%$ & \begin{tabular}{l|l} 
ha \\
\end{tabular} & $\%$ & ha & $\%$ & ha & $\%$ & ha & $\%$ & ha & $\%$ & ha & $\%$ & ha & $\%$ & \begin{tabular}{l|l} 
ha & \\
\end{tabular} & $\%$ & ha & $\%$ \\
\hline $1 z$ & 0 & 0 & 1 & 0 & 4 & 0 & 0 & 0 & 2 & 0 & 0 & 0 & 0 & 0 & 2 & 0 & 0 & 0 & 9 & 0 \\
\hline $2 z$ & 2098 & 11 & 1862 & 10 & 1292 & 7 & 1306 & 7 & 1447 & 8 & 1510 & 8 & 1215 & 7 & 1233 & 7 & 649 & 4 & 12611 & 69 \\
\hline $3 z$ & 1083 & 6 & 1099 & 6 & 725 & 4 & 580 & 3 & 638 & 4 & 508 & 3 & 483 & 3 & 533 & 3 & 149 & 1 & 5798 & 32 \\
\hline Total & \multicolumn{20}{|c|}{ Kamienna Góra district } \\
\hline $1 z$ & 0 & & 0 & & 0 & & 0 & & 0 & & 0 & & 0 & & 0 & & 0 & & 0 & \\
\hline $2 z$ & 1369 & 10 & 1600 & 12 & 2017 & 15 & 968 & 7 & 1000 & 7 & 929 & 7 & 897 & 7 & 1295 & 10 & 615 & 5 & 10689 & 79 \\
\hline $3 z$ & 359 & 3 & 388 & 3 & 483 & 4 & 224 & 2 & 318 & 2 & 280 & 2 & 280 & 2 & 354 & 3 & 104 & 1 & 2790 & 21 \\
\hline \multirow[t]{2}{*}{ Total } & 1728 & 13 & 1988 & 15 & 2500 & 19 & 1192 & 9 & 1318 & 10 & 1209 & 9 & 1177 & 9 & 1649 & 12 & 719 & 5 & 13479 & 100 \\
\hline & \multicolumn{20}{|c|}{ Kłodzko district } \\
\hline Total & \multicolumn{20}{|c|}{ Wałbrzych district } \\
\hline $1 z$ & 0 & & 0 & & 0 & & 0 & & 0 & & 0 & & 0 & & 0 & & 0 & & 0 & \\
\hline $2 \mathrm{z}$ & 1560 & 10 & 1480 & 10 & 1207 & 8 & 976 & 7 & 996 & 7 & 921 & 6 & 1126 & 8 & 964 & 6 & 665 & 4 & 9895 & 66 \\
\hline $3 z$ & 747 & 5 & 796 & 5 & 654 & 4 & 503 & 3 & 609 & 4 & 576 & 4 & 574 & 4 & 477 & 3 & 176 & 1 & 5111 & 34 \\
\hline \multirow[t]{2}{*}{ Total } & 2307 & 15 & 2276 & 15 & 1861 & 12 & 1480 & 10 & 1604 & 11 & 1497 & 10 & 1700 & 11 & 1441 & 10 & 841 & 6 & 15006 & 100 \\
\hline & \multicolumn{20}{|c|}{ Total } \\
\hline $1 z$ & 22 & 0 & 28 & 0 & 18 & 0 & 15 & 0 & 23 & 0 & 24 & 0 & 16 & 0 & 32 & 0 & 27 & 0 & 205 & 0 \\
\hline $2 z$ & 8408 & 10 & 8339 & 10 & 7498 & 9 & 5493 & 7 & 5823 & 7 & 6165 & 7 & 6313 & 8 & 6015 & 7 & 3175 & 4 & 57228 & 68 \\
\hline $3 z$ & 3806 & 5 & 3784 & 5 & 3274 & 4 & 2593 & 3 & 3168 & 4 & 3017 & 4 & 3077 & 4 & 2826 & 3 & 835 & 1 & 26379 & 32 \\
\hline Total & 12236 & 15 & 12150 & 15 & 10791 & 13 & 8100 & 10 & 9014 & 11 & 9206 & 11 & 9406 & 11 & 8873 & 11 & 4038 & 5 & 83813 & 100 \\
\hline
\end{tabular}


The Jelenia Góra district differed from the others in the share of grasslands with northern and north-eastern exposure $(17 \%$ and $16 \%)$ while in the Kamienna Góra district the eastern exposure prevailed (19\%).

Performed analysis showed that grasslands $2 \mathrm{z}$ are of utmost importance in the region because of occupied area (more than 57 thousand ha) and favourable distribution with respect to elevation a.s.l. and slope inclination. The complex is built of meadows and pastures of medium quality growing on mineral soils not flooded or periodically flooded and wet and on organic soils. Due to diverse habitat conditions the botanical composition represent a broad spectrum of species. Flat areas and lower parts of slopes are overgrown by communities with the prevalence of valuable fodder plants including grasses: Dactylis glomerata L., Festuca pratensis Huds., Alopecurus pratensis L., Poa pratensis L., legumes: Trifolium repens L., Trifolium pratense L., Lotus corniculatus L., Vicia craca L., herbs: Achillea millefolium L., Taraxacum officinale F.H. Wigg., Campanula patula L. and other whose total yield is 4.0 to $6.0 \mathrm{t} \mathrm{DM} \cdot \mathrm{ha}^{-1}$. Slopes with higher inclination are dominated by communities with grasses of medium to low value e.g.: Agrostis capillaris L., Festuca rubra L., Holcus mollis L., and a higher contribution of dicotyledons whose productive potential varies between 2.0 and $4.0 \mathrm{t} \mathrm{DM} \cdot \mathrm{ha}^{-1}$ (FATYGA and NADOLNA, 2009; MIKOŁAJCZAK, 1996). Soil and thermal conditions worsening in mountain areas with elevation and slope inclination result in decreased efficiency and fodder quality. For this reason, most productively important are the grasslands $2 \mathrm{z}$ situated up to $500 \mathrm{~m}$ a.s.1. (37 $000 \mathrm{ha}$ ), on flat areas and on slopes inclined not more than $6^{\circ}$ (38 $000 \mathrm{ha}$ ) which guarantees relatively stable efficiency of good quality fodder. The greatest potential of such grasslands was noted in the Kłodzko and Jelenia Góra districts. Meadows and pastures of the complex 2z situated between 500 and $700 \mathrm{~m}$ a.s.l. (19 $000 \mathrm{ha}$ ) and on slopes of inclination from 6 to $9^{\circ}$ (nearly 10000 ha) give smaller yields of less than $4.0 \mathrm{t} \mathrm{DM} \cdot \mathrm{ha}^{-1}$ and their largest areas can be found in the Kłodzko district. Grasslands situated above $700 \mathrm{~m}$ a.s.l. (c. $1200 \mathrm{ha}$ ) and on slopes inclined more than $9^{\circ}$ (almost 9000 ha) and those on periodically flooded or wet grounds have higher natural than economic value.

Grassland complex $3 z$ occupies more than 26000 ha in the region. It includes the grasslands on flooded areas with hampered water outflow, mid-forest grasslands and those on hardly accessible and poorly developed soils (FATYGA and NADOLNA, 2009). It is characterised by variable production and fodder quality. The share of grasses is small, dominating plants are: Festuca rubra L., Agrostis capillaris L., Holcus lanatus L., Deschampsia caespitosa (L.) P. Beauv, Anthoxantum odoratum L., Nordus stricta L., Briza media L., Cynosurus cristatus L., Helictotrichon pubescens (Huds.) Besser ex Schult. \& Schult, and herbs and weeds constitute $30-50 \%$ of plant cover. Their biomass production ranges between 2.0 and $3.0 \mathrm{t} \mathrm{DM} \cdot \mathrm{ha}^{-1}$. Important for fodder production are the areas situated in favourable conditions up to $500 \mathrm{~m}$ a.s.l. (c. $8000 \mathrm{ha}$ ) and on slopes up to $6^{\circ}$ inclination 
(c. 8500 ha). The greatest share of these grasslands was found in the Jelenia Góra district.

Low-production grasslands of the complex $3 \mathrm{z}$ and other grasslands situated on steep slopes $\left(>9^{\circ}\right)$ were excluded from afforestation programmes in 2007 (Journal..., 2007) to preserve and protect naturally valuable communities. They are represented by communities of high floristic diversity, containing rare and protected species (rich mountain hay meadows, xerothermic communities, mosses and sedges) (FATYGA and NADOLNA, 2009).

Very good grassland complex $1 \mathrm{z}$ occupies only 205 ha in the region. It occurs on mineral soils of various types that provide best conditions for the development of grassland vegetation. Valuable grasses with a large admixture of legumes prevail there and the yield may even exceed $8.0 \mathrm{t} \mathrm{DM} \cdot \mathrm{ha}^{-1}$.

Potential of the region is high even if only limited to meadows and pastures of the $2 \mathrm{z}$ complex. Situated in most favourable natural conditions (of the highest economic output) they cover an area of over 50000 ha.

Nowakowski et al. demonstrated that under natural conditions of mountain pastures in the Sudetes (400-600 m a.s.1.) 1 ha of grasslands can provide fodder for $2 \mathrm{LU}(500 \mathrm{~kg})$ of animals in the grazing season and for $1 \mathrm{LU}$ in an annual scale (NOWAKOWSKI, 2008; NOWAKOWSKI et al., 2000).

According to collected data, presented in tab. 4, ruminant stock in the region in 2008 was low and amounted: 24573 cattle, 3122 sheep, 925 goats and 2257

Table 4. The stock of ruminants and horses (in head) in mountain districts of the Sudetes in the years 2002 (Agricultural census) and 2008 (A set of data on selected communes in the Sudetes)

\begin{tabular}{|c|c|c|c|c|c|c|}
\hline \multirow{2}{*}{ Districts } & \multirow{2}{*}{ Years } & \multicolumn{2}{|c|}{ Cattle } & \multirow{2}{*}{ Sheep } & \multirow{2}{*}{ Horses } & \multirow{2}{*}{ Goats } \\
\hline & & total & cows & & & \\
\hline \multirow{3}{*}{ Jelenia Góra } & 2002 & 4849 & 2196 & 1910 & 555 & 489 \\
\hline & 2008 & 4129 & 1999 & 666 & 577 & 144 \\
\hline & difference & -720 & -197 & -1244 & +22 & -345 \\
\hline \multirow{3}{*}{ Kamienna Góra } & 2002 & 4681 & 2305 & 731 & 412 & 395 \\
\hline & 2008 & 5250 & 2500 & 730 & 205 & 200 \\
\hline & difference & +569 & +195 & -1 & -207 & -195 \\
\hline \multirow{3}{*}{ Kłodzko } & 2002 & 9798 & 4834 & 1749 & 1191 & 1441 \\
\hline & 2008 & 9834 & 4380 & 1505 & 1230 & 375 \\
\hline & difference & +36 & -454 & -244 & +39 & -1066 \\
\hline \multirow{3}{*}{ Wałbrzych } & 2002 & 5268 & 2502 & 330 & 545 & 533 \\
\hline & 2008 & 5360 & 2626 & 221 & 245 & 206 \\
\hline & difference & +92 & +124 & -109 & $-\mathbf{3 0 0}$ & -327 \\
\hline \multirow{3}{*}{ Total } & 2002 & 24596 & 11837 & 4720 & 2703 & 2858 \\
\hline & 2008 & 24573 & 11505 & 3122 & 2257 & 925 \\
\hline & difference & -23 & -332 & -1598 & -446 & -1933 \\
\hline
\end{tabular}


horses. Moreover, the herd of each animal groups decreased as compared with that in 2002, when large stock deficits had been already observed in relation to available food base (GŁĘBOCKI, 2006). The smallest changes were noted in cattle whose number decreased by 23 head with remarkable decline found in the Jelenia Góra district and a slight increase in the number in three other districts. Noteworthy was substantial decrease of dairy cows in the herd. The number of goats and sheep decreased to the largest extent, by 1933 and 1598 head, respectively. The greatest loss of sheep was recorded in the Jelenia Góra district and of goats - in the Kłodzko district. The number of horses decreased by 446 head in relation to the year 2002.

From collected data and from papers by other authors (TAŃSKA-HUS and OGEY, 2008) it appears that cattle is the most important group of animals in the livestock structure. In the year 2008, the stock of cattle - expressed in head per 100 ha of grasslands was 29 in the region and differed among particular districts being highest in the Kłodzko district $\left(66 \mathrm{head} \cdot 100 \mathrm{ha}^{-1}\right)$ and the lowest in the Jelenia Góra district ( $\left.22 \mathrm{head} \cdot 100 \mathrm{ha}^{-1}\right)$.

Based on these data, it can be concluded that there is a large dissonance between the production potential of grasslands in the Sudetes and the abundance of cattle and other herbivores. Productive role of grasslands still loses importance despite multi-directional support for agriculture in a form of areal subsidies, compensations for least favourable areas including those in foothill (350-500 $\mathrm{m}$ a.s.1.) and mountain ( $>500 \mathrm{~m}$ a.s.1.) zones and an attractive offer of agro-environmental programme. Withdrawal from agricultural use of grasslands and a lack of alternative ways of biomass utilisation poses a real risk for grassland stabilisation in the Sudetes.

Support within the common agricultural policy is not oriented to increasing animal production. Areal subsidies to grasslands in the first years after Poland's access to the EU were not associated with breeding animals. Reference animal payment was introduced in 2007 but the minimum animal stock of $0.3 \mathrm{LU} \cdot \mathrm{ha}^{-1}$ required for obtaining the payment allows for extreme extensification of animal production. There are no financial mechanisms promoting environmental-friendly ruminant breeding on permanent grasslands. Pasturage package was not considered in the agro-environmental programme for the years 2007-2013.

The problem of grassland utilisation in the Sudetes is not isolated in Europe. Resolution of the European Parliament of 23. September 2008 on the situation and perspectives of agriculture in mountain areas indicates an urgent need of elaboration the integrated strategy for sustainable development and utilisation of resources in such areas which would consider their differentiation (European Parliament Resolution, 2008). The resolution underlines the importance of separate treatment of mountain areas in a form of specific actions in favour of agriculture, whose significant part constitute grassland areas and associated animal production. 


\section{CONCLUSIONS}

The analysis of distribution of 83613 ha of grasslands in the Sudetes revealed that over $70 \%$ of their area is situated beneath $700 \mathrm{~m}$ a.s.l. and almost $75 \%$ - on slopes of an inclination $<9^{\circ}$. The greatest importance for fodder production have grasslands of the $2 \mathrm{z}$ complex whose area exceeds 57000 ha and those situated beneath $500 \mathrm{~m}$ a.s.l. and on slopes inclined less then $6^{\circ}$ constitute $45 \%$ of the total area. The largest fodder reserves are situated in the Kłodzko and Jelenia Góra districts.

Grasslands situated above $700 \mathrm{~m}$ a.s.l. - the upper limit of agriculture in the Sudetes - and on slopes inclined by more than $9^{\circ}$ (excluded from afforestation programmes) should be involved in activities aimed at preserving and protecting valuable plant communities.

Ruminant stock in four districts of the region in 2008 indicated an insufficient utilisation of fodder potential, particularly in the Jelenia Góra district.

\section{REFERENCES}

1. Fatyga J., 2003. The conditions of spatial restructuring of grassland management in the Sudetes. Journal of Water and Land Development, 7: 101-115.

2. FATYGa J., NAdOLnA L. 2009. Znaczenie niskoprodukcyjnych użytków zielonych w Sudetach na tle programów zalesieniowych. (Significance of low-production Sudetes grasslands against background afforestation programmes). Łąkarstwo w Polsce, 12: 27-36.

3. GŁĘBOCKI B., 2006. Zasoby trwałych użytków zielonych a natężenie chowu bydła i owiec na obszarach górskich Polski w latach 1988-2002. (Permanent grassland resources and the stocking rates of cattle and sheep in the mountain regions of Poland in the years 1988-2002). Problemy Zagospodarowania Ziem Górskich. PAN, Komitet Zagospodarowania Ziem Górskich, 53: 91-108.

4. Journal of Laws, as AT June 29, 2007. Decision of the Minister of Agriculture and Development of Rural Areas on specific conditions and procedures of granting financial support within the scope of action „Forestation of farmlands and forestation of land other than farmlands” covered with the Rural Development Programme for the years 2007-2013".

5. MiкOŁAJCZAK Z., 1996. Ekologiczne modele produkcji pasz na użytkach zielonych w Sudetach. (Ecological models of feed production on greengrasses of Sudety). Zeszyty Naukowe AR Wrocław, Konferencje 12, 291: 101-111.

6. NOWAKOWSKI P., 2008. Uwarunkowania i perspektywy chowu przeżuwaczy na górskich użytków zielonych. (Conditions and perspectives of ruminants keeping on mountainous grasslands). Problemy Zagospodarowania Ziem Górskich, 55: 113-121.

7. Nowakowski P., Dobicki A., MikoŁajczak Z., CwikŁa A., Nowak W., 2000. Model mieszanego wypasu przeżuwaczy dla naturalnego pastwiska górskiego. (Model of mixed grazing of ruminants on natural mountain pasture). Zeszyty Naukowe AR Wrocław, Zootechnika 47, 400: 161-176.

8. European Parliament Resolution of 23 September 2008 on the situation and outlook for hill and mountain farming, Procedure: 2008/2066(INI).

9. Spis rolny 2002 Dolnego Śląska. (Agricultural census 2002 Lower Silesia Voivodship). Wrocław. Urząd Statystyczny. CD. 
10. Stan i zmiany właściwości gleb użytkowanych rolniczo w województwie dolnośląskim w latach 2000-2005, 2007. (The state and changes of soil qualities in Lower Silesia Voivodship, 2000-2005). Puławy, IUNG: 223.

11. TAŃSKA-Hus B., OGŁY K., 2008. Produkcja zwierzęca w gospodarstwa górskich położonych w Sudetach. (Animal production in mountain farms located in Sudety). Problemy Zagospodarowania Ziem Górskich. PAN, Komitet Zagospodarowania Ziem Górskich, 55: 137-144.

12. Zestawienie danych dotyczących wybranych gmin w Sudetach, 2008. (A set of data on selected communes in the Sudetes). Wrocław, DODR: 1-58.

\section{STRESZCZENIE}

\section{Charakterystyka użytków zielonych w polskiej części Sudetów pod kątem możliwości produkcji pasz i ich ochrony}

Słowa kluczowe: Sudety, użtki zielone, produkcja paszy, pogłowie zwierzat

Górski region Sudetów dysponuje potencjałem produkcyjnym, umożliwiającym pozyskanie dobrej jakości paszy z użytków zielonych. Świadczy o tym korzystne usytuowanie przeważającej ich powierzchni, w 94\% znajdującej się do wysokości 700 m n.p.m., a w 75\% do $9^{\circ}$ nachylenia stoków. Łąki i pastwiska o największym znaczeniu gospodarczym zajmują powierzchnię przekraczającą 50000 ha. Największa ich część znajduje się w powiecie kłodzkim. Analiza stanu pogłowia przeżuwaczy i koni, z 2008 r. wykazała, że możliwości produkcji pasz przekraczają znacznie ich zapotrzebowanie. Produkcyjne wykorzystanie łąk i pastwisk traci na znaczeniu zwłaszcza $\mathrm{w}$ powiecie jeleniogórskim, mimo wsparcia finansowego w ramach Wspólnej Polityki Rolnej UE. 